\title{
Double-valve Replacement for Aortic and Tricuspid Autoimmune Endocarditis
}

\author{
Alvaro Sánchez ${ }^{1}$, Juan Parra ${ }^{2}$, ERIC VINCK ${ }^{2}$, Oscar Sanchez ${ }^{1}$, Federico Nunez ${ }^{2}$, Victor \\ Caicedo $^{2}$, and Ivette Jimenez ${ }^{3}$ \\ ${ }^{1}$ Fundacio Clinica Shaio \\ ${ }^{2}$ Affiliation not available \\ ${ }^{3}$ El Bosque University Faculty of Medicine
}

September 25, 2021

\begin{abstract}
Libman-Sacks endocarditis (LSE) is a cardiac manifestation of systemic lupus erythematosus and antiphospholipid syndrome and is characterized by non-bacterial verrucous vegetations with thrombogenic potential, causing stenosis and/or regurgitation in left heart predominantly, which can be asymptomatic in most of the cases but in the acute form it may present an infective form (pseudoinfective endocarditis) and complicate diagnosis and treatment. We present a case of aortic and tricuspid valve destruction due to Libman-Sacks endocarditis in a patient with antiphospholipid syndrome requiring surgical treatment by aortic and tricuspid valve replacement.
\end{abstract}

\section{Hosted file}

Libman Sacks JCS.docx available at https://authorea.com/users/436694/articles/538838-doublevalve-replacement-for-aortic-and-tricuspid-autoimmune-endocarditis

\section{Hosted file}

LSE eco.docx available at https://authorea.com/users/436694/articles/538838-double-valvereplacement-for-aortic-and-tricuspid-autoimmune-endocarditis

\section{Hosted file}

LSE Fig 2.docx available at https://authorea.com/users/436694/articles/538838-double-valvereplacement-for-aortic-and-tricuspid-autoimmune-endocarditis 